УДК 316.77:004

КРАЕВА Ольга Леонтьевна - доктор философских наук, профессор кафедры философии, социологии и теории социальной коммуникации Нижегородского государственного лингвистического университета им. Н.А. Добролюбова (603155, Россия, г. Нижний Новгород, ул. Минина, 31a)

\title{
СОЦИАЛЬНО-АНТРОПОЛОГИЧЕСКИЕ ОСНОВЫ УПРАВЛЕНИЯ В УСЛОВИЯХ СОВРЕМЕННОЙ ДЕМОКРАТИИ
}

Аннотация. С развитием антропологического подхода все большее теоретическое и практическое значение в науке получают исследования социально-антропологического потенциала современной жизни людей. Такой подход означает, что социальные процессы анализируются с учетом влияния на них человека, его потребностей и интересов, его личностных устремлений. В связи с этим возрастает значимость изучения социально-антропологических основ современной демократии и управления качеством жизни людей. В антропологическом ракурсе современных социальных исследований проявляет себя стремление науки проникнуть в глубинные, скрытые в самом человеке причины социальных явлений. Ключевые слова: социально-антропологический потенциал, человеческий потенциал, человеческий капитал, субъектный потенциал, качество жизни, индикаторы социального развития, демократия, гуманизация социальных отношений, информационно-коммуникативные технологии, социально-антропологические основы управления

$\mathrm{B}$ ажнейшими завоеваниями современного периода развития цивилизации являются происшедшие в мире существенные изменения в направлении демократизации стран, увеличение степени открытости политических систем и расширение политических свобод.

Демократическое устройство общества, следование конституционным нормам предполагают постоянную заботу о соблюдении прав и свобод граждан и представляют собой гарантию и основу достойного уровня и качества жизни людей. Демократически организованное общество и его институты способны многое сделать для этого в системном порядке, используя свойственные ему методы управления и самоуправления. Однако далеко не всегда реализация и даже осознание тех возможностей, которые свойственны демократическим режимам и гражданской инициативе людей, осуществляются в современном государстве. Во многом это связано с процессами глобализации, которые порой наносят ощутимый урон отлаженной системе государственного регулирования, а значит и правового регулирования различных стран. Изменения, которые в результате претерпевает демократия, иногда превращают ее в свою полную противоположность, в чем можно усмотреть свойственные ей кризисные тенденции. Они вполне объяснимы в условиях кризисов современной цивилизации, которые под влиянием глобализационных процессов тоже носят глобальный и системный характер.

Следование стандартам качества жизни, на которые ориентируется современное общество, не всегда является результатом специфической системной самоорганизации, свойственной демократическим государствам. Но в современных условиях повышенной значимости науки, образования, информации, когда увеличивается их доля в управлении качеством жизни людей и в выработке программ развития демократических общественных институтов в этом направлении, требования качества жизни соединяются с демократическим устройством общества и его институтами. Осознание взаимосвязи ценностей демократии и развития человеческого потенциала свойственно мировому сообществу совре- 
менного периода и находит свое проявление в аналитических исследованиях и программах развития человека, осуществляемых различными международными организациями и форумами, в использовании современных информационно-коммуникативных технологий в целях продвижения и реализации культурно-образовательных проектов глобального масштаба. Появившись в прошлом вместе с идеалами и ценностями демократии, ценности просвещения и развития человека распространились сейчас во всем мире, где в большинстве стран установились демократические режимы правления, следующие принципам демократии, принятым мировым сообществом. Уровень образования стал важнейшим индикатором прогресса этих стран, включенным в индексы развития человеческого потенциала и интеллектуального потенциала общества. Соотнесенность ценностей демократии и развития человеческого потенциала в прошлом и в настоящем, таким образом, доказана самой историей человеческой цивилизации и может рассматриваться как ее закономерность.

Ее исследование представляет собой важную научную и практическую задачу в современных условиях, когда развитие науки и образования определяет перспективы и отдельных государств, и человеческой цивилизации в целом. В соответствии с этим повышается значение исследований социально-антропологического потенциала, качества жизни и направлений их совершенствования, развития методологии подобного рода исследований. В современной науке получили развитие теоретические основания и инструментарий эмпирических измерений для таких исследований: теория человеческого потенциала и его индикаторы, теория человеческого капитала и его измерители, теория качества жизни и его измерители, качественные и количественные методы в социально-гуманитарных науках, многочисленные индикаторы и показатели антропологического измерения в развитии стран и регионов. Эти подходы и измерители могут быть использованы для изучения вопросов управления качеством жизни в современном обществе и служить практическому внедрению результатов исследований в виде выводов о социально-антропологических основах управления качеством жизни.

Задачи изучения новых возможностей человека в современной социальной действительности вызвали появление учения о потенциале человека, которое развивается в настоящее время в стране и в мире. Содержание, которое наука сегодня вкладывает в понятие потенциала человека, имеет концептуальную основу в философии, что методологически значимо для многих частных наук, изучающих человека. Учение о потенциале способно стать основой развития новой научной теории человека, что можно видеть в развитии современного знания о человеке. Концепция потенциала имеет сегодня большое прикладное значение, т.к. в соответствии с ней строятся различные измерители социально-экономического прогресса общества, включающие значения, связанные с потенциалом человека. Существующие в науке концепции общественного развития, при всех различиях во взглядах на перспективы общества и человека, отмечают одну общую тенденцию - что будущее существование и развитие общества связано с развитием человеческого потенциала и высвобождением сущностных, творческих, универсальных его сторон. В связи с этим не случайно, что индекс развития человеческого потенциала становится в настоящее время универсальным для всех стран измерителем общественного прогресса и представляет собой индекс достижений в области базовых возможностей человека в трех основополагающих сферах: это долгая и здоровая жизнь, уровень образования и доход.

Большое значение в проблематике потенциала человека имеет вопрос о соотношении потребностей и способностей в системе потенциала. Разработка этой 
проблемы раскрывает механизм действия и формирования потенциала человека, истоки и механизм формирования и активности личности. Эта проблема имеет два ключевых аспекта:

- определение функций той и другой силы в этом соотношении;

- определение закономерностей этого взаимодействия и их соотношения с закономерностями становления и развития личности.

В отечественной философии эта проблема чаще всего понимается как проблема диалектики потребностей и способностей. В современной западной философии эта проблема формулируется не столь однозначно.

Но и в том и в другом случае с уровнем развития человеческого потенциала соотнесено решение не только гуманитарных и социальных проблем, но и проблем экономического развития. В соответствии с учением о человеческом потенциале разрабатываются концепция человеческого потенциала и принципы его индикации, концепция человеческого капитала и др. Они призваны стать методологической основой человеческого измерения развития регионов, территорий, стран мира. На основе различных подходов к измерению условий жизни человека и уровня его развития выстраивается сегодня целый ряд индикаторов и интегральных индексов, позволяющих осуществить такие измерения.

В рассматриваемых показателях отражены стратегические приоритеты развития современного общества - такие, например, как уровень образования. Индикатор образования включен в индекс развития человеческого потенциала, о котором говорилось выше, в индекс интеллектуального потенциала общества, который отражает уровень образования населения и состояние науки. Индекс человеческого капитала на душу населения показывает уровень затрат государства, фирм, граждан на социальную сферу, включая образование. Существуют и другие показатели антропологического потенциала общественного развития: индикаторы качества жизни, индекс нищеты, индекс развития с участием гендерного фактора, коэффициент жизнеспособности населения.

Таким образом, в науке происходит процесс становления, накопления статистических показателей для определения степени развития стран, регионов в зависимости от развития человека и условий, создаваемых для этого. Однако существующие индикаторы носят несколько упрощенный характер. Поэтому продолжает быть актуальной задача концептуального анализа потенциала, который способен был бы стать основанием разработки системы индикаторов для определения перспектив общества в соответствии с уровнем развития человеческого потенциала.

Развивая социально-антропологические основы управления, необходимо учитывать, что потенциал человека нужно рассматривать как субъектный по своей сути. Субъектность представлена в разной мере у разных людей, но присутствует в человеческом потенциале всегда. Соответственно, и адресоваться к ней в сферах коммуникации, образования, науки, управления можно по-разному: либо развивая и реализуя, либо подавляя и манипулируя. Процесс накопления и реализации субъектного потенциала является более сложным, но вместе с тем ориентированным на развитие гуманистических и демократических основ общества. Стремление подчинить и использовать в чужих интересах субъектный потенциал людей распространено сегодня в большей степени, но это не решает проблем развития и реализации субъектных возможностей человека, а следовательно и гуманистических задач. Более всего в отношении субъектного потенциала противостоят друг другу экономические устои общества и его демократические основы. Востребованность субъектных возможностей человека возрастает, к нему так или иначе обращены все сферы его жизни, 
включая экономические и политические. Однако именно они далеко не всегда заинтересованы в повышении роли субъектного потенциала людей в жизни общества и даже стремятся оказывать давление с целью воздействия на человека и его выбор. Наиболее явно обозначенное противоречие обнаруживает себя, например, в периоды политических и экономических кризисов, предвыборных кампаний, во многих современных информационно-коммуникативных технологиях.

Важную роль в преодолении отмеченного противоречия может сыграть концепция человеческого капитала, которая развивается современной наукой и применяется в практике развития экономик ведущих стран мира. Задачи развития экономики она связывает с ростом человеческого капитала (способности, знания, профессиональные навыки, мотивация), который должен способствовать росту производительности труда и производства, что ведет к росту доходов и стимулирует работника делать вложения в здоровье, образование, развивать свой потенциал, чтобы эффективно реализовать его. В результате человеческий капитал начинает выступать ведущим фактором, обеспечивающим рост экономики и прогресс стран мира. Это побуждает государства увеличивать инвестиции в развитие человека. Согласно проведенным исследованиям, инвестиционные потоки, направляемые в человеческие ресурсы в странах развитой экономики, вышли в число главнейших, что очень важно в условиях современной экономики, когда ценность человеческих ресурсов повышается. С качественными изменениями человеческих ресурсов оказываются связанными главные особенности экономического развития ведущих стран мира на протяжении прошлого века.

Вместе с тем направление преодоления рассмотренного противоречия можно видеть в неразрывной связи с субъектным потенциалом новых возросших возможностей науки и образования, в их воздействии на общество и его развитие. В управлении обществом решающей также становится власть знаний и информации, что влечет за собой активизацию больших масс людей и повышение определяющей роли их субъектного потенциала в жизни общества. Новые процессы в жизни общества могут стать новым объектом социально-антропологических исследований в направлении развития представлений о ценностях демократии и новой роли человеческого потенциала и его субъектных возможностей в условиях демократического устройства общества.

В связи с рассмотренными выше особенностями современной социальной действительности становится понятной приверженность современных стран демократическим идеалам и ценностям, которую можно объяснить взаимовлиянием развития демократии и человеческого потенциала. Именно в развитии демократических устоев государств усматривается взаимосвязь развития человека и социальных условий его жизни. На это обратило внимание и мировое сообщество, когда ясно обозначились приоритеты развития человеческого потенциала, знаний, науки и образования на современном этапе общественного прогресса. Выявляя социально-антропологические основы управления современным обществом, не следует забывать о тех изменениях в понимании человека и общества, которые произошли в науке и философии, изменениях в самом обществе и условиях жизни человека и о тех исторических событиях, которыми сопровождались демократические изменения и которые многое в опыте прошлого заставляют переосмыслить. Переосмысление должно осуществляться прежде всего в направлении значимости развития активности человека и условий, которые создают для этого демократические режимы. В соответствии с этим основные факторы и этапы формирования и эволюции демократических режимов и идей демократии совпадают с важнейшими вехами формирования и 
эволюции гражданского общества и правового государства, которые составили основу демократической общественно-политической системы. В современном демократическом обществе человек наделен целым рядом прав и свобод, позволяющих активно участвовать в политической деятельности, деятельности общественных организаций, в управлении государственными делами, осуществлении гражданских инициатив. В свою очередь, гражданское общество основано на верховенстве права в обществе, свободе людей, их равенстве в правах, что в правовом государстве служит источником юридического законодательства. Таким образом, взаимодействие всех составляющих демократического общества служит приоритету человека, его прав и свобод, что закреплено в конституционном принципе гуманизма как главенствующем, а значит способствует развитию его потенциала, опоре на человеческий потенциал и включенности его во все сферы общественной жизни.

Анализируя особенности взаимосвязи ценностей демократии и развития человеческого потенциала на современном этапе развития цивилизации, следует обратиться и к той новой роли, которую выполняет в обществе человек, и к тем новым условиям, в которых это происходит. Обращаясь в современных условиях к анализу социальной реальности, нельзя не учитывать тот факт, что она изменилась под влиянием новых информационных технологий. Современная общественно-историческая эпоха рассматривается как информационно-технологическая, а в перспективе - как образовательно-технологическая. Существенно изменилась роль знаний, информации в социальной действительности, усилилось их влияние на ее трансформацию, в т.ч. на особенности демократии и на возможности и перспективы самого человека. Перспективы развития общества философы, социологи и футурологи связывают с гуманизацией информационно-коммуникативной реальности и развертыванием ее антропологического содержания. И это столь же важно для развития демократии и социально-антропологических основ управления, создающих условия для возрастания значения субъектного потенциала человека; и различные социальные сферы, включая информационно-коммуникативную, в своем функционировании не могут не адресоваться ему.

Учитывая динамику изменений, происходящих в обществе, и существующие затруднения в выработке мировоззренческой позиции личности в контексте развития и изменений ценностных приоритетов общества, что особенно касается молодых людей, философия и наука должны не просто вырабатывать новые подходы к исследованию и оценке происходящего, но и продвигать свои идеи с использованием современных информационно-коммуникативных возможностей и применять их в образовании и семейном воспитании гражданских ценностей и гражданской активности. Базовую роль в решении этих воспитательных задач играют конституционные нормы, которые ориентированы на демократические нормы и принципы, принятые в современном мире, и главенствуют в действующем законодательстве и жизни российского общества. Ведущая роль современных демократических ценностей в системе ценностных ориентаций российских граждан, их пропаганда и воспитание способны повлиять на развитие гуманистических установок личности и служить важнейшим регулятором жизни современного общества.

Таким образом, благодаря развитию социально-антропологического знания открывается возможность сравнить по целому ряду показателей степень развития и уровень жизни стран мира в социальной и экономической сферах и использовать полученные данные в управлении обществом в целях гуманизации его отношений в интересах широких масс людей.

Вместе с тем в современной философии и науке доказывается активная дея- 
тельная сущность человеческого потенциала, его связанность с системой ценностных ориентаций человека. Такое понимание человеческого потенциала согласуется с главным принципом демократии, на котором строили представление об обществе, государстве, человеке мыслители прошлого, - с принципом свободы. В соответствии с ним свобода рассматривается и как неотъемлемое качество человека, способность к свободному целеполаганию, и как необходимое условие жизни людей в обществе. На этой основе выстраиваются демократические устои государства и демократические ценности. Учитывая закономерно возрастающую роль субъектного потенциала человека в истории и активное проявление этой закономерности в жизни современного общества, можно прогнозировать, что прогрессивное развитие общества и государства будет и в дальнейшем связано с демократическими ценностями и принципами.

KRAEVA Olga Leont'evna, Dr.Sci. (Philos.), Professor of the Chair of Philosophy, Sociology and Theory of Social Communication, Dobrolubov State Linguistics University of Nizhny Novgorod (31a Minina St, Nizhny Novgorod, Russia, 603155)

\section{SOCIAL AND ANTHROPOLOGICAL BASIS OF MANAGEMENT IN CONDITIONS OF MODERN DEMOCRACY}

Abstract. With the development of the anthropologic approach in science, the study of the socio-anthropological potential of the modern life of people has received a great theoretical and practical importance. Such an approach means that social processes are analyzed taking into account the influence of a person on them, his needs and interests, his personality and aspirations. In this regard, the importance of studying the socio-anthropological foundations of modern democracy and managing the quality of life of people is increasing. In the anthropological perspective of modern social research, the science is trying to penetrate into the deepest causes of social phenomena hidden in man himself.

Keywords: social and anthropological potential, human potential, human capital, subject potential, quality of life, indicators of social development, democracy, humanization of social relations, information and communication technology, socioanthropological bases of management 